\title{
Rooftop Urban Agriculture Model with Two Tomato Varieties (Lycopersicum esculentum Mill) and Toppings in the High Jungle - Peru
}

\author{
José Alomía-Lucero ${ }^{1}$, Jorge Castro-Bedriñana ${ }^{*}, 2$, Doris Chirinos-Peinado ${ }^{2}$ \\ ${ }^{1}$ Faculty of Agricultural Sciences, Universidad Nacional del Centro del Perú, Satipo, Perú \\ ${ }^{2}$ Faculty of Zootechnics, Universidad Nacional del Centro del Perú, Huancayo, Perú
}

\begin{tabular}{l} 
A R T I C L E I N F O \\
\hline Article history: \\
Received: 20 January, 2020 \\
Accepted: 12 February, 2020 \\
Online: 25 February, 2020
\end{tabular}

Keywords:

Agroecological system

Food security

Organic tomato

Urban nutrition

Sustainable urban agriculture

Rooftop tomato crops

\section{Introduction}

The temperature of the atmosphere in the world during the $21 \mathrm{st}$ century will continue to increase between 1.0 and $3.7{ }^{\circ} \mathrm{C}$, depending on greenhouse gas emissions [1]; This is expected based on the results obtained from the average of the latest generation of the Earth System Models; so, the global climate will continue in significant warming in response to emissions of $\mathrm{CO}_{2}, \mathrm{CH}_{4}$ and other greenhouse gases into the atmosphere [2].

The behavior of the maximum temperature and the corresponding thresholds of heat waves have been studied in different places of our planet; In the north-west of the city of Mexicali-Mexico, in recent decades, there is a tendency to increase the temperature, added to a greater number of days with maximum temperatures considered as heat waves [3].

In Perú, the Intergovernmental Panel on Climate Change (IPCC) has collated and reported impacts at the global and regional scales, and global-scale studies concur that Peru is currently highly vulnerable to water stress, with significant variation in the climate across the country.

\footnotetext{
*Jorge Castro-Bedriñana, Av. Mariscal Castilla Nº 3909, El Tambo-Huancayo.

+51964408057. jorgecastrobe@yahoo.com

www.astesj.com

https://dx.doi.org/10.25046/aj050157
}

The climate of the Amazon basin is dominated by the Intertropical Convergence Zone (ITCZ), which each year gives very high rainfall (3000 $\mathrm{mm}$ per average year). As Peru spans tropical latitudes $0-18^{\circ} \mathrm{S}$, the altitude of the midday sun is never far from vertical and mean monthly temperature is almost constant through the year, particularly so in the cloudy Amazon Basin where the mean temperature is $26^{\circ} \mathrm{C}$ throughout the year, rising to $30-32{ }^{\circ} \mathrm{C}$ in daytime and falling to $21-22^{\circ} \mathrm{C}$ at night [4].

Hot temperature can place many demands on society and can have serious negative impacts over food production and public health. Between variety of methodological approaches, the adaption of agricultural practices to changing climate conditions its included [5], and an adaptation strategy to avoid dangerous levels of climate change would be the use of green roofs.

Climate change has generated many problems, and the intervention of various professions linked to food production in urban environments must be strengthened to improvement the food security of vulnerable populations [6]. The strategy of "greening" the urban space and ensuring the condition of durability of afforestation is necessary to reverse current 
development trends and their negative effects on the environment and quality of life of people in the urban environment [7].

Urban agriculture is a strategy of environmental sustainability, promoted by green urbanism, and has the ability to meet the multiple demands of food through a considerable diversity of orientations and appropriated technologies [8].

Urban agriculture has great potential to improve the space and life of cities. The installation of orchards and green roofs humanizes the city and becomes more pleasant and comfortable; The humanization of the city involves re-naturalizing it [9]. The naturalizing of roofs with vegetables on light substrates due to the lower weight facilitates their handling on a roof of urban housing [10].

In this context, the objective of the research was to evaluate the components that interact in the design of the system of a model of urban agriculture on roofs with three types of vegetable covers and cultivation of two varieties of tomato (Lycopersicum esculentum Mill) in the central jungle of Peru.

\section{Methods}

\subsection{Study place}

The investigation was carried out between January and December 2017 in the city of Satipo, located between the geographical coordinates of South Latitude $11^{\circ} 15^{\prime} 11^{\prime \prime}$ and West Longitude $74^{\circ} 38^{\prime} 14^{\prime \prime}$, on the eastern foothills of the Andes Mountains, between the Cordillera Oriental and the Amazonian Plain, in the department of Junín. Most of its territory is located in the High jungle and Low jungle ecoregion (dry tropical climate) at an altitude between 207 to $628 \mathrm{~m}$ and has a vast biological diversity considered among the richest in the world. It has an area of 81,600 ha.

\subsection{Rooftop urban agriculture system design}

The dynamic agroecological system design considered:

- Identifying system elements, inputs, processes and outputs.

- Spatial distribution of wooden drawers, with adequate distance for tomato plants per drawer. Three drawers were considered for the Cherry tomato variety and three for the Río Grande variety.

- Design of the model with tomato plants and cover plants.

\subsection{Biological material}

The urban rooftop farming system considered tomato crops of the Cherry and Rio Grande varieties and cover plants under conditions of central jungle, Luffa cylindrica, Mucuna pruriens and Cyclantera pedata.

\section{Results and discussion}

\subsection{Design of the urban agriculture system of roofs with tomato and vegetable covers}

Figure 1 shows the system model with the components of inputs, processes and outputs that are detailed below:
A. Inputs:

Solar energy as a source of energy for photosynthesis, heavy rain as a source of water for plants, and air as a source of oxygen, carbon dioxide and nitrogen.

\section{B. Processes:}

- On the soil level: The substrate of agricultural land conditioned in wooden boxes on the roof, in which biological processes of insects and microorganisms for the decomposition of organic matter occur; These allow the biological and chemical fertility of the soil.

- At the producer level: Tomatoes, vegetable covers and weeds, making photosynthesis to transform solar energy into chemical carbohydrate energy accumulating in stems, leaves, fruits and seeds.

- At the first-order consumers level: Hens, arthropods such as pest insects and pest mites, the human family, which feed on the vegetables produced. At the level of microbes: Phyto parasitic nematodes, phytopathogenic fungi, phytopathogenic pseudo fungi, phytopathogenic bacteria and phytopathogenic viruses, symbiotic bacteria of the legume root.

- At the second-order consumers level: Insectivorous and aracnivorous wild birds, hunting spiders, bio controller pests, predatory mites, entomopathogenic fungi, and entomopathogenic bacteria.

- At the decomposer level: Microbes such as facultative fungi and saprophytes, saprophytic bacteria of the soil organic matter.

\section{Outputs:}

Tomato seeds and fruits, Mucuna and vegetable sponge seeds, free range chicken eggs, and poultry hens for meat.

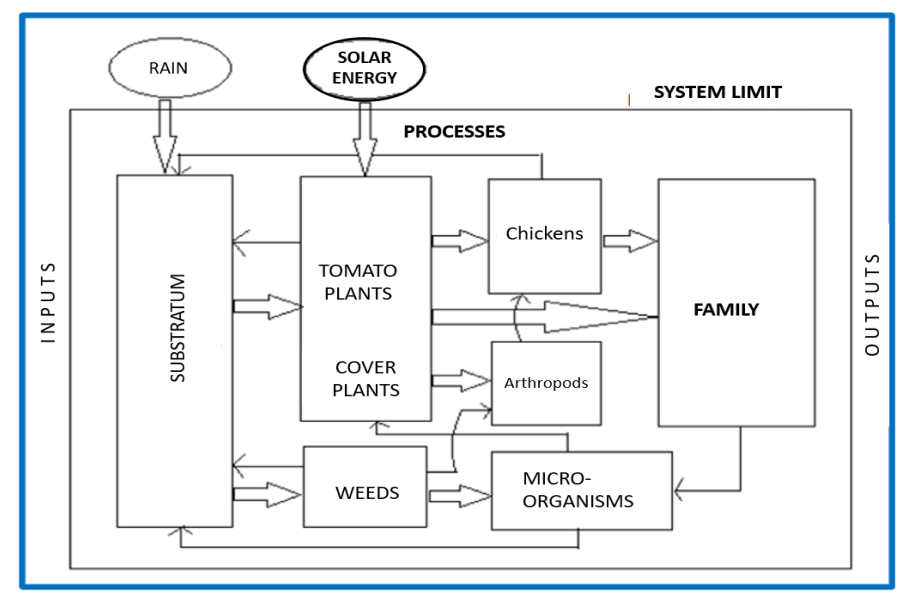

Figure 1. Design of the urban agriculture system of roofs with tomato and vegetable covers

Figure 2 show the spatial distribution of the wooden drawers with the corresponding distance equivalent to $2.70 \mathrm{~m}^{2}$. Four tomato plants per drawer were considered; The Cherry Tomato variety was grown in three drawers, and the Rio Grande tomato variety in three other drawers; at the ends cover plants were installed, two floors in each drawer. 


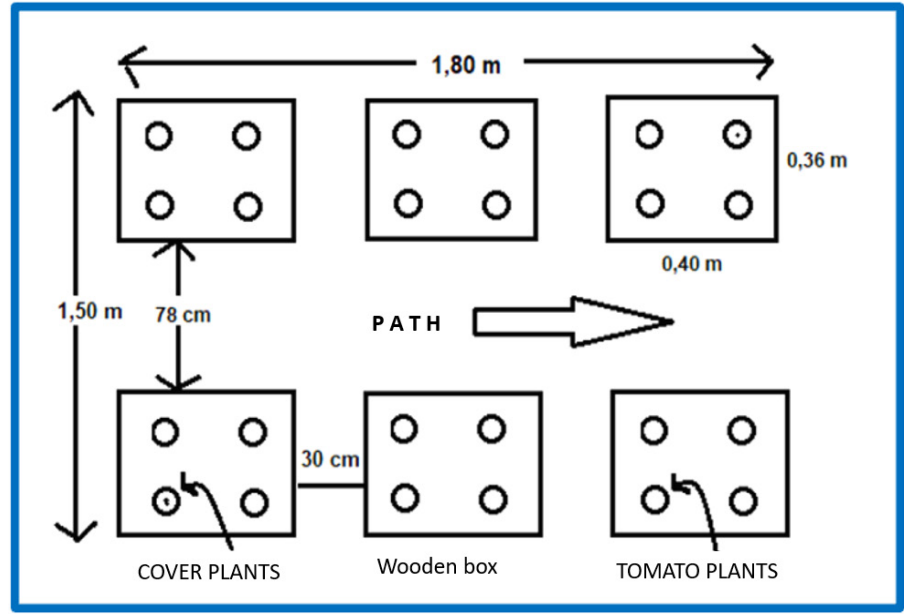

Figure 2. Plan view of the urban rooftop agriculture model with tomato and vegetable covers

Figure 3 show the plan view of the model where tomato plants and cover plants can be seen in the system built with wood. The height of the model generates a volume of $3.51 \mathrm{~m}^{3}$. The cover plants generate shade to balance the strong hours of sun that support the roofs and the plants.

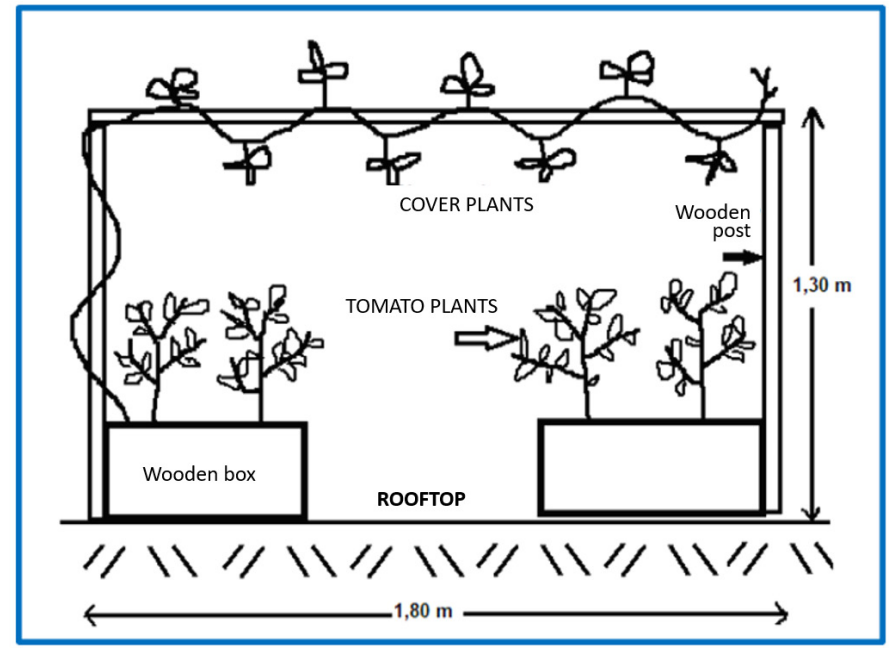

Figure 3. Profile view of the urban agriculture model of roofs with tomato and vegetable covers

Figure 4 shows photographs of the growing Lycopersicum esculentum plants, at the beginning with their roof covering plants and ground level.

\subsection{Design of the rooftop urban agriculture system model}

The Agroecological system inputs are abundant solar energy, rainwater and air with high humidity, which allow the tropical zone to be favorable for plant cultivation. These natural resources allow ecological processes, being at ground level as a substrate of plants, where insects, annelids and microbes that make biological fertility. This low weight substrate has been conditioned in drawers for plants useful growing on the roofs.

At the level of producers, tomato plants, vegetable covers and weeds, perform photosynthesis to transform solar energy into chemical energy which accumulate in the stems, leaves, fruits and seeds. The crops sown and the weeds that arrive by the wind settle in the little substrate and prosper thanks to the abundance of water and sunlight, some are beneficial plants. The important thing about this is that organic tomatoes are harvested that are very healthy [11].

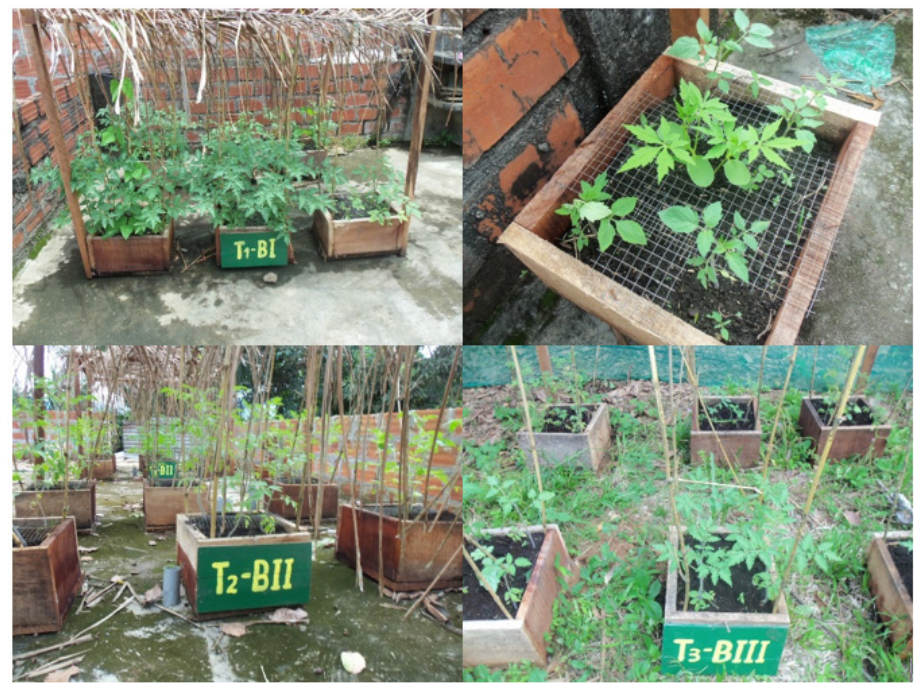

Figure 4. Growing Lycopersicum esculentum plants

At the level of first-order consumers, hens feed on the vegetables produced, arthropods and insects [12]. At the microbial level, there are phytoparasitic nematodes, phytopathogenic fungi, phytopathogenic pseudo-fungi, phytopathogenic bacteria and phytopathogenic viruses, and the symbiotic bacteria from legume roots make the system a stable unit.

At the level of second-order consumers, there are insectivorous and aracnivorous wild birds that visit the roofs, hunting spiders, bio controller pests, predatory mites, entomopathogenic fungi and entomopathogenic bacteria. Thus, allowing the ecological balance of the system and to protect biodiversity the use of pesticides for pest control is not necessary [13]. At the decomposing level there are annelids, centipedes, hat fungi, microbes such as facultative fungi and saprophytes, saprophytic bacteria from the soil's organic matter; These organisms allow the system to recycle its organic matter by giving the plants nutrients again.

The outputs are tomato fruits, tomato seeds, mucuna seeds and vegetable sponge, eggs and chicken meat for the benefit of the family, making the system important for food security [8]. Not only vegetables are produced but also animal products [14].

The rooftop agroecosystem has soil, plants, animals and microbes, which form the food pyramid in ecological balance, which allows the sustainability of the system; has higher organic matter, nematode abundances and well tomato fruit yield [15].

The production benefits the family with safe tomatoes, free of pesticides [16]; At the same time there is a plant barrier on the roofs to reduce the effects of solar radiation that harm those who live in the city [17]. In this way the study is framed in the nature of cities with green roofs with ecological benefits [18].

These results demonstrate that roof agriculture is a sustainable alternative, since a place of cement contributes to global warming can now be used for horticultural plants cultivation such as the 
tomato Variety Rio Grande, that tolerates high temperatures [19] of the tropical climate of the high jungle.

At soil level the M. pruriens, C. pedata and L. cylindrica cover plants find a natural environment suitable for their development and show a high biomass yield, result observed in other study with M. puriens [20].

This urban rooftop farming system strengthen food production and food security in cities in a context of vocational training and education in sustainable development, climate change and food, is reinforced [6]. The nature of roofs as one of the alternatives to increase green areas in cities is also urgent as a global proposal [10].

As a complementary result, a new tomato variety was obtained by natural the crossing between the Cherry and Rio Grande varieties. When crossing its stems and floral clusters there was an exchange of pollen from the Rio Grande variety to the Cherry variety. This new strain, which is genetically is F1, has early and late blight tolerance characteristics, with fruits twice as large as Cherry variety, but Rio Grande flavor. This is explained because the tomato is a plant that can be crossed by being close by pollinating insects, which can carry pollen from another plant on their legs and make such pollination.

The equatorial and polar diameters of a sample of 15 tomato cross fruits taken at random from the average were $3.01 \pm 0.17$ and $2.47 \pm 0.26 \mathrm{~cm}$, higher values than the diameters of the Cherry variety, but smaller than the Rio Grande variety.

The equatorial and polar average diameters of a sample of 15 cross tomatoes taken at random were $3.01 \pm 0.17$ and $2.47 \pm 0.26$ $\mathrm{cm}$; values greater than the diameters of the Cherry variety, but smaller than the Rio Grande variety. The equatorial diameter is similar to that obtained in the Cherry variety by fertigation, but greater than the polar diameter found by [21], specifying that tomatoes have been organically produced in our case.

A new tomato variety that tolerates heat and blight would be a good alternative for the production of organic tomatoes by reducing inorganic inputs and contributing to the preservation of the environment $[22,23]$. This study contributes with scientific evidence for food production and consumption in urban areas, and the relationships among city, human well-being and ecosystems [24].

\section{Conclusions}

The agroecological system designed has with principal inputs the solar radiation, rainwater and air as main sources for plant photosynthesis. The rooftop agroecosystem components are soil, plants, animals and microbes, which form the food pyramid in ecological balance. Production benefits the family in terms of food safety with safe pesticide-free tomatoes. At the same time there is a plant barrier on the roofs to reduce the solar radiation effects that favors the comfort of the family; in this way the work is framed in the nature of cities with green roofs with their multiple ecological benefits.

A new tomato variety obtained by natural crossbreeding between the Cherry and Rio Grande varieties has also been obtained, with medium-sized fruits favorable to the organic tomato market, whose equatorial and polar diameter is 2.82 and $2.47 \mathrm{~cm}$.

\section{Conflict of Interest}

The authors declare no conflict of interest.

\section{Acknowledgment}

To the families that kindly allowed to install green roofs for the development of the study.

\section{References}

[1] IPCC. Climate Change 2013: The Physical Science Basis. Contribution of Working Group I to the Fifth Assessment Report of the Intergovernmental Panel on Climate Change. Cambridge University Press. 2013. [OnLine]. Available:https://www.ipcc.ch/site/assets/uploads/2017/09/WG1AR5_Fron tmatter_FINAL.pdf.

[2] T. Anderson, E. Hawkins, and P. Jones P. $\mathrm{CO}_{2}$, the greenhouse effect and global warming: from the pioneering work of Arrhenius and Callendar to today's Earth System Models. Endeavour, vol. 40. no. 3, pp. 178-187. 2016. doi: 10.1016/j.endeavour.2016.07.002.

[3] P. Austria and R. Bandala. Maximum Temperatures and Heat Waves in Mexicali, Mexico: Trends and Threshold Analysis. Air Soil and Water Research, 2016, no. 9, pp. 21-28. doi: 104137-ASWR-S322778.

[4] Met Office. Climate: Observations, projections and impacts: Peru. Department of Energy \& Climate Change. Met Office. Devon, EX1 3PB United Kingdom. 2011. [OnLine] Available: http://eprints.nottingham.ac.uk/2040/18/Peru.pdf

[5] J. Luck, M. Spackman, A. Freeman, P. Tre, bicki, W. Griffiths, K. Finlay and S. Chakraborty. Climate change and diseases of food crops. Plant Pathology, vol. 60, no. 1, pp. 113-121. 2011. doi:10.1111/j.1365-3059.2010.02414.x

[6] M. Chávez y J. Palacios. Importancia de los cursos de agricultura urbana ante el cambio climático y la seguridad alimentaria en México. Grupo eumed.net/Universidad de Málaga y Red Académica Iberoamericana LocalGlobal. México, vol 10. no 28. 2017. [OnLine]. Available: http://www.eumed.net/rev/delos/28/cursos-agricultura.html

[7] M. Cantón, C. De Rosa y H. Kasperidus. Sustentabilidad del bosque urbano en el área metropolitana de la ciudad de Mendoza. Análisis y diagnóstico de la condición de las arboledas. Avances en Energías Renovables y Medio Ambiente, vol. 7, no 1, pp. 29-34 2003. [OnLine]. Available: https://www.mendoza-

conicet.gob.ar/asades/modulos/averma/trabajos/2003/2003-t001-a006.pdf

[8] A. Nadal, E. Cuerva, I. Cerón, A. Josa y J. Rieradevall. Agricultura en edificios urbanos: metodología para la implementación de invernaderos en azoteas de áreas no residenciales urbanas. A: Congreso Internacional Towards Green Cities. "Towards green cities 2016: Compendio de Investigación Académica". Mérida: 2016, p. 429-438. [OnLine]. Available: URI http://hdl.handle.net/2117/100341

[9] R. Marín. La agricultura urbana en el metabolismo de la ciudad: la "burbuja hortícola" de Barcelona y sus elementos de transformación social. XII Congreso Español de Sociología: Grandes Transformaciones Sociales, nuevos desafíos para la sociología. 2016. [OnLine]. Available; http:/www.fes-sociologia.com/la-agricultura-urbana-en-el-metabolismode-la-ciudad-la-burbuja-hort/congress-papers/2578/

[10] R. Leonardo. Biofertilizantes como opción de naturación de azoteas en zonas urbanas. Universidad Nacional Autónoma de México, Tesis Biología Zaragoza. 76 pp. 2013. [OnLine]. Available: https://www.zaragoza.unam.mx/portal/wpontent/Portal2015/Licenciaturas/ biologia/tesis/tesis_leonardo_lopez.pdf

[11] C. Márquez-Hernández, P. Cano-Ríos, Y. I. Chew-Madinaveitia, A. Moreno-Reséndez y N. Rodríguez-Dimas. Sustratos en la producción orgánica de tomate cherry bajo invernadero. Producción orgánica de tomate cherry bajo invernadero. Revista Chapingo Serie Horticultura, vol 12, no. 2, pp. 183-189, 2006.

[12] D. Józefiak and R. Engberg. Insects as poultry feed. Insects in Poultry and Fish Nutrition Conference. 20th European Symposium on Poultry Nutrition Prague, Czech Republic. 2015. [OnLine]. Available: https://www.researchgate.net/publication/281373491

INSECTS_AS_POULTRY_FEED

[13] S. Sepúlveda. Metodología para estimar el nivel de desarrollo sostenible en territorios. Biograma. San José, C.R. IICA 2008. 119 pp. [OnLine]. Available: http://repiica.iica.int/docs/B0664e/B0664e.pdf

[14] Organización de las Naciones Unidas para la Agricultura y la Alimentación - FAO. Agricultura urbana. 2015. [OnLine]. Available: www.fao.org/urbanagriculture/es/ 
[15] J. Reeves, Z. Cheng, J. Kovach, M. Kleinhenz and P. Grewal. Quantifying soil health and tomato crop productivity in urban community and market gardens. Urban Ecosyst 17, pp 221-238. 2014. https://doi.org/10.1007/s11252-013-0308-1

[16] Azoteas Verdes de Guadalajara. Manual de Agricultura Urbana. pp. 16. 2012. [OnLine]. Available: https://blogdeazoteasverdes.files.wordpress.com/2012/10/manualagricultura-urbana.pdf

[17] M. Valbuena. Implementación de un modelo de techo verde y su beneficio térmico en un hogar de Honda, Tolima (Colombia) Bogotá. Pontificia Universidad Javeriana. P. 67. 2012. [OnLine]. Available: https://repository.javeriana.edu.co/bitstream/handle/10554/8985/RhodesVal buenaMateode2012.pdf? sequence $=1$ \&isAllowed $=y$

[18] M. H. Zaar. Agricultura urbana: algunas reflexiones sobre su origen y expansión. Biblio 3W. Revista Bibliográfica de Geografía y Ciencias Sociales. Barcelona: Universidad de Barcelona, vol. XVI, no. 944, p. 15. 2011. [OnLine]. Available: http://www.ub.es/geocrit/b3w-944.htm.

[19] J. Santiago, M. Mendoza y F. Borrego. Evaluación de tomate (Lycopersicon esculentum, Mill) en invernadero: Criterios fenológicos y fisiológicos. Agronomía Mesoamericana, vol. 9, no. 1, pp. 59-65, 1998. [OnLine]. Available: http://www.mag.go.cr/rev_meso/v09n01 059.pdf.

[20] Vega P.F. y Leblanc H. Producción de biomasa y fijación de nitrógeno de Mucuna pruriens en el trópico húmedo de Costa Rica. Tierra Tropical. vol. 9 no. 1, pp. 57-65, 2013. Available: http://usi.earth.ac.cr/glas/sp/Documentos\%202015/ Producci\%C3\%B3n\%20de\%20biomasa\%20y\%20fijacion\%20de\%20nitrog eno.pdf

[21] H. A. Raza et al., "Analysis the effect of 500kv High-Voltage Power Transmission Line on the Output Efficiency of Solar-Panels," in 2019 International Conference on Electrical, Communication, and Computer Engineering (ICECCE), 2019, pp. 1-6.

[22] L. Salas, J. González, M. García, E. Sifuentes, S. Parra y P. Preciado. Calidad biofísica y nutracéutica de frutos de tomate producido con sustratos orgánicos. México. Revista Electrónica Nova Scientia. vol. 8, no. 2, pp. 310325. 2016.

[23] M. Florido y M. Álvarez M. Reseña bibliográfica: Aspectos relacionados con el estrés de calor en tomate (Solanum lycopersicum L.) Cultivos Tropicales, vol. 36, no. especial, pp. 77-95. 2015

[24] F. Orsini, D. Gasperi, L. Marchetti, C. Piovene, S. Draghetti, S. Ramazzotti, G. Bazzocchi and G. Gianquinto. Exploring the production capacity of rooftop gardens (RTGs) in urban agriculture: the potential impact on food and nutrition security, biodiversity and other ecosystem services in the city of Bologna. Food Security, vol. 6, no. 6, pp.781-792. 2014. doi:10.1007/s12571-014-0389-6. 